\title{
DANCING IN THE DARK: AN ANALYSIS OF THE LIVE ENTERTAINMENT INDUSTRY AND THE DECEPTIVE MARKET PRACTICES OF TICKETMASTER AND LIVE NATION
}

\author{
ERIK HOLMSTROM* \\ Lay down your money and you play your part \\ Everybody's got a hungry heart \\ —Bruce Springsteen, “Hungry Heart,” The River (1980)
}

\section{INTRODUCTION}

It's the same old song and dance. It's just been announced that a famous band will be playing in town and tickets go on sale in two weeks. Ticket sale day finally comes, and your computer is on. You are logged into Ticketmaster and the clock strikes 10:00 a.m. Yet, before you can even select your tickets, the entire concert is sold out. This pain may be all too familiar to fans of legendary Canadian rock band The Tragically Hip, who went on a final tour in 2016 after Gord Downie, their lead singer, announced that he had a terminal brain tumour. ${ }^{1}$ Two thirds of the available tickets were immediately scooped up by "ticket bots," which are software programs capable of searching for and purchasing enormous numbers of tickets from primary ticket sites like Ticketmaster. ${ }^{2}$ Consequently, many fans were forced to resort to purchasing tickets at inflated prices on the secondary ticketing market, using sites such as StubHub or TicketsNow. This is not the first time the secondary ticketing market has presented problems for fans.

In early 2009, Bruce Springsteen and the E Street Band announced their "Working on a Dream" tour in Springsteen's home state of New Jersey. ${ }^{3}$ Almost immediately, fans reported experiencing "technical malfunctions" during ticket sales. Some fans were forwarded to Ticketmaster's subsidiary, TicketsNow — a secondary ticketing site-despite seats still being available through Ticketmaster. This error resulted in some fans being forced to pay "prices four

\footnotetext{
Copyright (C) 2019 by ERIK HOLMSTROM.

* Erik Holmstrom would like to especially thank his partner, Stephenie Kirk, for her support.

${ }^{1}$ David Common, “'There's a Big Problem': Two-thirds of Tragically Hip Tickets Weren't Sold Directly to Fans”

(21 October 2016), online: $C B C$ News <www.cbc.ca/news/business/tickets-bots-tragically-hip-marketplace-

$1.3811658>$.

${ }^{2}$ Ibid.

3 Daniel Kreps, "Bruce Springsteen 'Furious' At Ticketmaster, Rails Against Live Nation Merger" (4 February 2009), online: Rolling Stone <www.rollingstone.com/music/music-news/bruce-springsteen-furious-at-ticketmasterrails-against-live-nation-merger-97368/>.
}

https://doi.org/10.5206/uwojls.v9i2.8070 
times greater than their actual face value." ${ }^{4}$ However, once the New Jersey Attorney General announced an investigation into the malfunction, Ticketmaster issued an apology, explaining that the company had "decided to send some buyers to the company's secondary-ticketing company TicketsNow in an attempt to put more tickets into the hands of Bruce Springsteen fans." The company eventually reimbursed fans for the difference between the face value and the cost of secondary tickets.

Additional controversy surrounded the ticketing monolith after a joint undercover investigation by $\mathrm{CBC}$ News and the Toronto Star. The investigation uncovered a plot by Ticketmaster to recruit professional scalpers to "cheat its own system" and "squeeze more money out of fans." ${ }^{\prime 6}$ Ticketmaster's objective was to charge additional fees on resold tickets. ${ }^{7}$ After Ticketmaster collected fees from the sale of the initial ticket, the company collected a second fee upon resale.

In 2018, the Competition Bureau decided to investigate Ticketmaster and its parent company, Live Nation, after Canada's Economic Development Minister, Navdeep Burns, contacted the bureau's office. ${ }^{8}$ The Commissioner of Competition filed an application pursuant to section 74.01 of Canada's Competition Act. ${ }^{9}$ The application alleges that, among other things, Live Nation, Ticketmaster, and its subsidiaries have engaged in and continue to engage in deceptive marketing practices stemming from their mandatory fees.

Tickets purchased through Ticketmaster are riddled with fees on top of the ticket's original price. These "service fees," "order processing fees," and "facility charges" only become visible after a customer selects their tickets and provides certain information. These fees add an additional 30 to 40 percent to the ticket cost. This practice is not only frustrating for consumers, but is arguably deceptive. ${ }^{10}$ This article seeks to assess the likely outcome of the Competition Bureau's application and considers potential solutions to this problem.

The article begins with a brief explanation of the structure of the live entertainment industry, followed by a description of Live Nation and Ticketmaster's roles therein. The article then analyzes the recent allegations of deceptive practices against Live Nation and Ticketmaster brought forward by the Commissioner of Competition under the Competition Act. The article

\footnotetext{
${ }^{4}$ Zachary H Klein, "Who's the Boss? The Need for Regulation of the Ticketing Industry" (2010) 5:1 Brook J Corp, Fin \& Com L 185 at 185, online: <brooklynworks.brooklaw.edu/bjcfcl/vol5/iss1>.

${ }^{5}$ Caryn Ganz, "Ticketmaster Apologizes to Bruce Springsteen After Onsale Blunder" (5 February 2009), online: Rolling Stone <www.rollingstone.com/music/music-news/ticketmaster-apologizes-to-bruce-springsteen-afteronsale-blunder-95571>.

${ }^{6}$ Dave Seglins, Rachel Houlihan \& Laura Clementson, "A Public Relations Nightmare: Ticketmaster Recruits Pros for Secret Scalper Program," (19 September 2018), online: CBC News <www.cbc.ca/news/business/a-publicrelations-nightmare-ticketmaster-recruits-pros-for-secret-scalper-program-1.4828535>.

${ }^{7}$ Ibid.

${ }^{8}$ CBC, "Competition Bureau to Investigate Ticketmaster after CBC News/Toronto Star Scalper Investigation" (26 September 2018), online: $C B C$ News <www.cbc.ca/news/politics/competition-bureau-to-investigate-ticketmaster$1.4839904>$.

${ }^{9}$ RSC 1985, c C-34.

${ }^{10}$ Ben Sisario, “A Band Battles Ticketmaster on Sales Fees" (15 May 2012), online: The New York Times <www.nytimes.com/2012/05/16/arts/music/string-cheese-incident-takes-on-ticketmaster.html>.
} 
puts forward potential solutions and concludes that federal legislation must be implemented to curb deceptive practices within the primary market, thereby restricting the use of ticket bots and scalpers.

\section{HOW THE ENTERTAINMENT INDUSTRY IS ORGANIZED}

Despite the ease of access to live videos on the Internet and the ability to instantly share live experiences with friends through social networking services, the global concert market has continued to increase in recent years. With a total revenue of US\$6.7 billion in $2007,{ }^{11}$ the net proceeds of ticket sales from the primary market alone will reach an anticipated US $\$ 24.55$ billion by $2021 .{ }^{12}$ However, as this industry grows, the number of competitors is beginning to dwindle because of vertical integration. Therefore, it is first necessary to understand how this enormous industry is structured in today's market.

At the forefront of the entire industry are the artists or bands, since they are the commodity desired by the consumer. To reach their audience, these artists or bands hire managers or agents "who represent them and take a share of their earnings in exchange for their managerial services." 13 Through their managers, the performers contract a promoter who organizes the live concerts. The payment structure between bands and promoters has been compared to that between authors and their publishers. ${ }^{14}$ This may be best illustrated by an example:

Suppose that the band Angrist's Instruments contracts with Ron's Promotions to perform a single concert. The band receives a "guaranteed advance"; for example, a sum equal to the first $\$ 100,000$ of ticket sales. Then, before additional revenue is distributed, the promoter, Ron, recovers his expenses and a "guaranteed profit," say $\$ 50,000$ for expenses and $\$ 22,500$ for profit. The expenses could include advertising, rent for the venue, the cost of unloading equipment, and so forth. The promoter and the band then split any ticket revenue above the guarantee, plus expenses and minimum profit (above $\$ 172,500$ in this case), usually with the band receiving 85 percent and the promoter receiving 15 percent of these revenues. This arrangement probably describes around three quarters of contracts. The band's guaranteed advance and percentage of revenue after expenses is higher for bands with greater bargaining power. ${ }^{15}$

\footnotetext{
${ }^{11}$ Alan J Meese \& Barak D Richman, “A Careful Examination of the Live Nation-Ticketmaster Merger” (25 November 2009) at 5, online: William \& Mary Law School Research Paper No 09-41, DOI: $<10.2139 /$ ssrn.1542626>.

12 Jon Chapple, “Concert Ticket Market to Top \$24bn By 2021” (17 February 2017), online: IQ Magazine <www.iq-mag.net/2017/02/concert-ticket-market-top-24bn-2021-technavio/\#.W-82I5NKjOQ>.

${ }^{13}$ Alan B Krueger, "The Economics of Real Superstars: The Market for Rock Concerts in the Material World" (2005) 23:1 J Labor Economics 1 at 3, DOI: <10.1086/425431>.

${ }^{14}$ Meese \& Richman, supra note 11 at 6; Krueger, supra note 13 at 4.

${ }^{15}$ Krueger, ibid at 4.
} 
These contracts impose significant financial risks on the promoter and band, both of whom may suffer when shows are poorly attended. The promoter is also responsible for contracting with a suitable concert venue, which in turn will assist in providing "services such as parking, concessions, sponsorship, and band-related merchandise."16 The revenue generated is largely determined by the price of concert tickets, which is agreed upon by the promoter and the performers or their manager. ${ }^{17}$

Once the ticket price is set, the promoter or venue will hire a ticket distribution company to sell and distribute tickets to customers through its website or other methods, such as "the venue's box office, and, in some cases, directly by the band to its fan club." 18 However, the Internet has made box offices and call centres relatively obsolete. The contracts between the ticket distributor, promoter, and venue outline the "processing fees" that will be charged on top of a ticket's face value, and the revenue generated from these fees is distributed between the distributor and promoter or venue. ${ }^{19}$

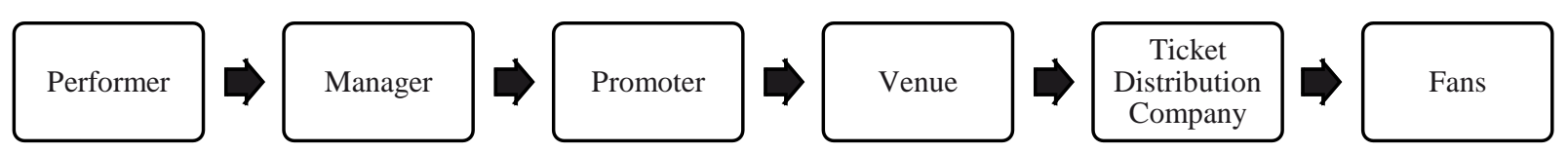

Figure 1: Flow of Participants in Live Entertainment Industry

The number of tickets available for any event is typically determined by the size of the venue. However, many of these tickets are not made available for sale to the general public. Instead, tickets are held back by the promoter, venue, record company and others, such as fan clubs. ${ }^{20}$ In 2016, an investigation in New York City by the Attorney General found that over 50 percent of an average show's tickets were set aside, with 16 percent going to "insiders" and another 38 percent being held for presale. ${ }^{21}$

A multi-year investigation by the Attorney General of New Jersey into Ticketmaster's handling of the 2009 Bruce Springsteen shows in New Jersey determined that "of the 38,778 seats made available for the two shows ... only 6,000 people were able to buy tickets for one or more of these seats." 22 The remaining tickets were redirected to secondary sites and an additional 10,494 tickets were set aside for the band, record label, sponsors, and the booking agent. This led

\footnotetext{
${ }^{16}$ Meese \& Richman, supra note 11 at 5.

${ }^{17}$ Ibid at 7.

${ }^{18}$ Krueger, supra note 13 at 4.

${ }^{19}$ Meese \& Richman, supra note 11 at 8.

${ }^{20}$ Klein, supra note 4 at 196-97.

21 "AG Schneiderman Announces Findings of Investigation into Consumer Abuses in Live Entertainment Industry" (28 January 2016), online: New York State Office of the Attorney General <ag.ny.gov/press-release/agschneiderman-announces-findings-investigation-consumer-abuses-live-entertainment>.

22 Dave Itzkoff, "Springsteen Tickets Scarce in New Jersey," The New York Times (21 May 2009), online: <www.nytimes.com/2009/05/22/arts/music/22arts-SPRINGSTEENT_BRF.html>.
} 
one commentator to note in exasperation that fans may have a "better chance of becoming a member of Mr. Springsteen's E Street Band" than attending the show. ${ }^{23}$

Ticket sale prices in the primary market are also increasing at a much higher rate than inflation, as measured by the consumer price index (see Figure 2). As a result, fewer buyers are able to afford tickets. With such a lack of supply, many consumers are forced to purchase through the secondary ticketing market. However, this option does not provide the relief consumers are looking for in price.

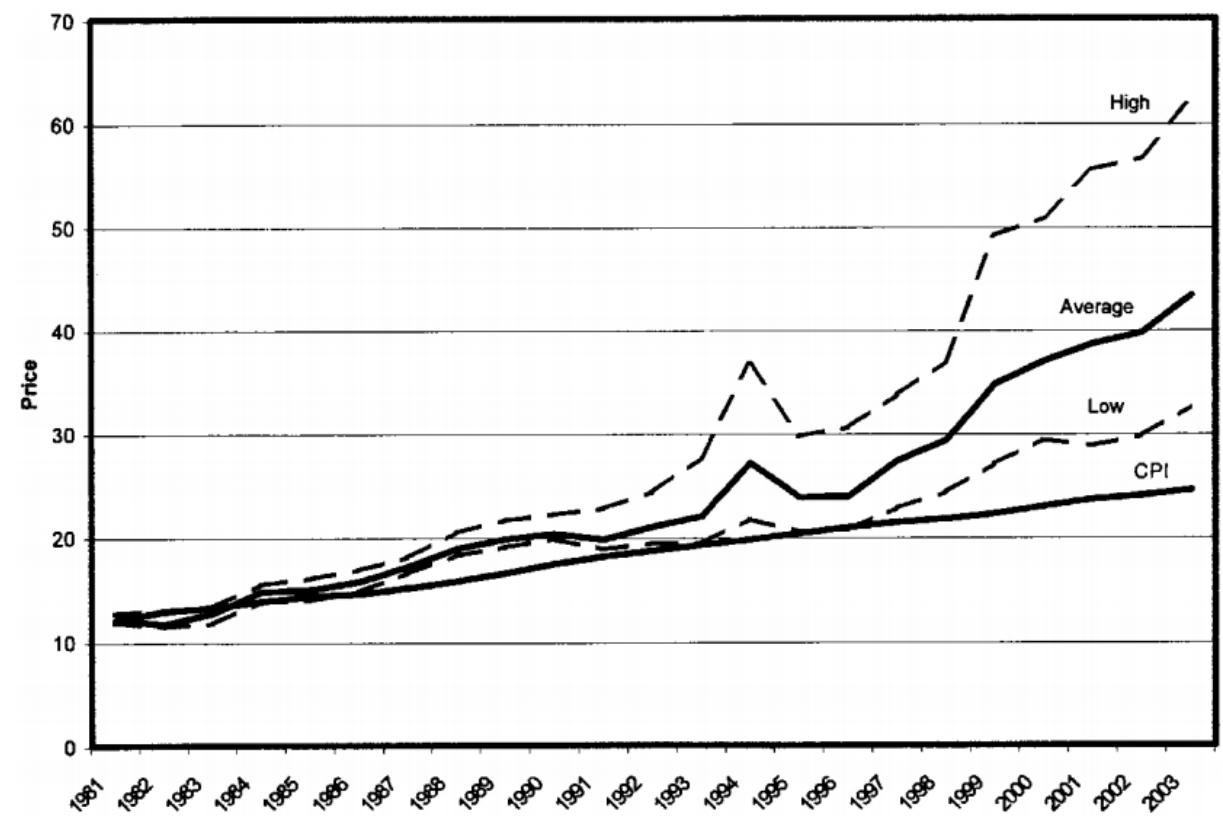

Figure 2: Average price per concert ticket, high- and low-price tickets, and overall inflation rate, 1981-2003. ${ }^{24}$

\section{The Secondary Market}

The secondary market is, in essence, online ticket scalping. Original ticket purchasers are able to resell their tickets on sites such as StubHub, TicketCity, and TicketsNow. It has been estimated that, as of 2015, the total revenue of the secondary market is around five billion dollars. ${ }^{25}$ Because of these secondary market websites, the ability to obtain concert tickets has drastically changed.

A significant reason for this change is the proliferation of ticket bots. Ticket bots have revolutionized the ticket market through their ability to "search and purchase mass quantities of

\footnotetext{
23 Ibid.

${ }^{24}$ Krueger, supra note 13 at page 7.

${ }^{25}$ Zack Guzman, "The Surreptitious Rise of the Online Scalper," CNBC (4 March 2015), online:

<www.cnbc.com/2015/03/04/online-ticket-resellers-the-surreptitious-rise-of-the-online-scalper.html>.
} 
tickets in seconds from ticket vendor websites."26 Ticketmaster stated in 2013 that sometimes "60 percent of the most desirable tickets for some shows" have been acquired by ticket bots. ${ }^{27}$ For example, in 2014, within the first minute of ticket sales, a single scalper used a ticket bot to acquire 1,012 tickets to a $\mathrm{U} 2$ concert. $^{28}$

While some users see the value in the secondary market as a way to rid themselves of tickets for events they can no longer attend, the secondary market also provides a platform for others to resell tickets at exorbitant prices. Typically, promoters charge "lower than market prices so that the event's tickets may be affordable to ordinary fans." ${ }^{29}$ However, ticket scalpers can resell purchased tickets above market prices for events in high demand. ${ }^{30}$ Some concert tickets are marked up as much as 72 to 453 percent above face value. ${ }^{31}$

Consumers are not the only ones unhappy with the concert ticket system. Many performers, including Elton John, have aligned themselves with concertgoers, calling the secondary market "disgraceful." "32 The Foo Fighters attempted to solve the problem themselves on their "Beat the Bots" tour. Fans could purchase presale tickets at the box office through a lottery-style method. ${ }^{33}$ However, fans were soon disappointed to find that ticket scalpers also appeared, eventually selling tickets at marked-up prices. ${ }^{34}$

Bruce Springsteen, for his "Springsteen on Broadway" tour, attempted to curb the problem through Ticketmaster's Verified Fan service, which requires fans to sign up and register before tickets go on sale. The service analyzes customers by "looking at their data, including e-mail addresses and past ticket purchases," to try to determine whether they are likely a fan or a scalper. ${ }^{35}$ If the customer does not appear to be a scalper, they are allowed better access to tickets through a code. Other artists, such as Taylor Swift, implemented a "boost" program that, based on how much merchandise they purchased, placed fans ahead in the ticket line, which caused some controversy. ${ }^{36}$

\footnotetext{
${ }^{26}$ Nevra Azerkan, "Sold Out? Why the Music Industry Needs to Urge Lawmakers to Regulate How Concert Tickets Are Distributed" (2018) 38:2 Whittier L Rev 130 at 131.

${ }^{27}$ Ben Sisario, “Concert Industry Struggles With 'Bots' That Siphon Off Tickets,” The New York Times (26 May 2013), online: <www.nytimes.com/2013/05/27/business/media/bots-that-siphon-off-tickets-frustrate-concertpromoters.html>.

${ }^{28}$ New York State Office of the Attorney General, supra note 21.

${ }^{29}$ Phyllis L Zankel, "Wanted: Tickets: A Reassessment of Current Ticket Scalping Legislation and the Controversy Surrounding Its Enforcement” (1992) 2:1 Seton Hall J Sports L 129 at 144.

${ }^{30}$ Klein, supra note 4 at 191-92.

${ }^{31}$ Kelli B Grant, "How to Avoid Sky-High Summer Concert Ticket Prices," CNBC (21 May 2015), online: <www.cnbc.com/2015/05/21/how-to-avoid-sky-high-summer-concert-ticket-prices.html>.

${ }^{32}$ Mark Savage, "Sir Elton John: Secondary Ticket Prices 'Disgraceful,” BBC News (16 December 2015), online: <www.bbc.com/news/entertainment-arts-35091230>.

${ }^{33}$ Mark Carpowich, "Foo Fighters Ticket Experiment: Five Reasons It Didn't Work," The Huffington Post (25 January 2015), online: <www.huffingtonpost.com/mark-carpowich/foo-fighters-ticket-exper_b_6217552.html>. ${ }^{34}$ Ibid.

${ }^{35}$ Steve Knopper, "Inside Bruce Springsteen and Taylor Swift's War on Scalpers, Ticket Bots," Rolling Stone (11 September 2017), online: <www.rollingstone.com/music/music-news/inside-bruce-springsteen-and-taylor-swiftswar-on-scalpers-ticket-bots-201770>.

${ }^{36}$ Ibid.
} 
Despite the efforts made by artists, ticket scalping still continues. In fact, instead of attempting to thwart the secondary market, many primary ticket sellers have acquired secondary market businesses, such as Live Nation's purchase of TicketsNow. ${ }^{37}$ In effect, these vertical integrations have resulted in Live Nation and Ticketmaster running the entertainment industry.

\section{WHO ARE LIVE NATION AND TICKETMASTER?}

Live Nation Entertainment, Inc. (Live Nation) is a global entertainment company, operating in more than 200 venues. It is currently the world's largest concert promoter. ${ }^{38}$ In 2017 alone, it promoted around 30,000 shows and sold roughly 500 million tickets. ${ }^{39}$ It is organized and exists under Delaware's laws, but its headquarters are located in Beverly Hills, California. ${ }^{40}$

Ticketmaster is a business that provides "ticketing services to venues, promoters, sports teams and leagues and to ticketholders who wish to resell their tickets." ${ }^{41}$ With over 80 percent of the US market share, Ticketmaster leads the way as the "dominant ticket platform in the primary ticket market." 42 Ticketmaster also has contracts with 80 of the top 100 concert venues. ${ }^{43}$ Its revenue is derived from service fees attached to ticket prices. The company also acquired the secondary market ticketing company, TicketsNow, in 2008. This acquisition enabled Ticketmaster to generate over US\$900 million from the resale market by $2014 .{ }^{44}$

In 2010, Ticketmaster and Live Nation merged to create Live Nation Entertainment, Inc., an entertainment juggernaut. ${ }^{45}$ The company now occupies a diverse set of business streams, including promotion, venue management, ticketing, sponsorship, artist management, and other ventures. ${ }^{46}$ Critics have found that the merger resulted in little to no change in the industry. ${ }^{47}$

\footnotetext{
${ }^{37}$ Ben Sisario, "Ticketmaster Accuses 21 of Fraudulent Ticket Buying" (1 May 2013), online: The New York Times <www.nytimes.com/2013/05/02/business/media/ticketmaster-targets-scalpers-in-federal-lawsuit.html>.

${ }^{38}$ Ben Sisario \& Graham Bowley, "Live Nation Rules Music Ticketing, Some Say With Threats" (1 April 2018), online: The New York Times <www.nytimes.com/2018/04/01/arts/music/live-nation-ticketmaster.html>.

${ }^{39}$ Ibid.

${ }^{40}$ The Commissioner of Competition v Live Nation Entertainment, Inc, Live Nation Worldwide, Inc, Ticketmaster Canada Holdings ULC, Ticketmaster Canada LP, Ticketmaster LLC, The VIP Tour Company, Ticketsnow.com, Inc, and Tnow Entertainment Group, Inc, "Notice of Application" (25 January 2018) at para 10, online: Competition Tribunal <www.ct-tc.gc.ca/CasesAffaires/CasesDetails-eng.asp?CaseID=429> [Competition Tribunal, "Application"].

${ }^{41}$ The Commissioner of Competition v Live Nation Entertainment, Inc, Live Nation Worldwide, Inc, Ticketmaster Canada Holdings ULC, Ticketmaster Canada LP, Ticketmaster LLC, The VIP Tour Company, Ticketsnow.com, Inc, and Tnow Entertainment Group, Inc, "Response" (12 March 2018) at para 14, online: Competition Tribunal <www.ct-tc.gc.ca/CasesAffaires/CasesDetails-eng.asp?CaseID=429> [Competition Tribunal, "Response"].

${ }^{42}$ Tianxin Zou \& Baojun Jiang, "Can Musicians and Fans Benefit When a Primary Ticket Platform Controls the Resale Market? Theory and Evidence” (15 June 2018) SSRN Electronic Journal at 2, DOI: $<10.2139 /$ ssrn.3203293>.

${ }^{43}$ Ibid.

${ }^{44}$ Ibid.

${ }^{45}$ Nathan B Grzegorek, "The Price of Admission: How Inconsistent Enforcement of Antitrust Laws in America's Live Entertainment Sector Hurts the Average Consumer" (2010) 44:1 John Marshall L Rev 261 at 271-72.

${ }^{46}$ Sisario, supra note 38.

${ }^{47}$ Ibid.
} 
Recently, Live Nation faced criticism for using its "control over concert tours to pressure venues into contracting with its subsidiary, Ticketmaster," which, if true, could constitute a violation of American antitrust law. ${ }^{48}$ Live Nation and Ticketmaster's grip on the entertainment industryand their ability to act as the major ticket seller, venue operator, promoter, and artist managerenables the companies to charge higher ticket prices and enforce hidden fees, or drip pricing. ${ }^{49}$

Drip pricing is a marketing technique in which a business advertises a certain price, only to reveal hidden, mandatory fees later on in the purchasing process. The process is typically found in e-commerce settings, where websites lead consumers through several web pages to complete a single transaction. Drip pricing can be "misleading to consumers because the advertised price is not attainable." ${ }^{50}$ While drip pricing is not mentioned anywhere in Canadian law, or in the Competition Act, the Competition Bureau argues that certain sections of the Act are "principle-based prohibitions that apply to a wide array of reviewable matters," including drip pricing. ${ }^{51}$ Recently, the Competition Bureau has been particularly active in combatting drip pricing to ensure "truth in advertising in Canada's digital economy." 52 In 2017, the Competition Bureau issued a news release explaining that ticket vendors needed to "review their marketing practices and display the real price of tickets upfront." 53

\section{THE COMPETITION ACT AND FALSE OR MISLEADING ADVERTISING}

The Competition Bureau is an independent law enforcement agency governed by the Competition Act that investigates and enforces "price-fixing cartels, anti-competitive mergers and dominant firms that abuse their market power, as well as misleading advertising and other deceptive marketing practices." 54 The Bureau is headed by the Commissioner of Competition, who is responsible for enforcing and administering the Act. ${ }^{55}$ Upon application, the Competition Bureau may appear before the Competition Tribunal - a specialized, independent six-member tribunal of federal court judges - to determine whether a business contravenes the Act. ${ }^{56}$

The Competition Bureau reviews deceptive marketing practices, such as false or misleading representations. Originally, deceptive marketing practices were not addressed in legislation. However, because of "concerns with fraudulent land sales in western Canada," they

\footnotetext{
48 Ibid.

${ }^{49}$ Ibid.

50 "Calling All Ticket Vendors: Be Upfront About the True Cost of Tickets" (4 July 2017), online: Competition Bureau Canada <www.canada.ca/en/competition-bureau/news/2017/06/calling_all_ticketvendorsbeupfront aboutthetruecostoftickets.html> [Competition Bureau, "News Release"].

${ }^{51}$ The Commissioner of Competition v Live Nation Entertainment, Inc, Live Nation Worldwide, Inc, Ticketmaster Canada Holdings ULC, Ticketmaster Canada LP, Ticketmaster LLC, The VIP Tour Company, Ticketsnow.com, Inc, and Tnow Entertainment Group, Inc, "Reply" (26 March 2018) at para 27, online: Competition Tribunal <www.cttc.gc.ca/CasesAffaires/CasesDetails-eng.asp?CaseID=429> [Competition Tribunal, "Reply"].

52 Competition Bureau, "News Release", supra note 50.

${ }^{53}$ Ibid.

${ }^{54}$ John Pecman, "Unleash Canada's Competition Watchdog: Improving the Effectiveness and Ensuring the Independence of Canada's Competition Bureau" (2018) 31:1 Can Competition L Rev 5 at 7.

${ }^{55}$ Competition Act, supra note 9, s 7(1).

${ }^{56}$ Competition Tribunal Act, RSC 1985, c 19 (2nd Supp), ss 3(2), 8(1).
} 
were implemented in 1914 as criminal offences under the Combines Investigation Act. ${ }^{57}$ Later, in 1999, civil remedies were added to address "certain drawbacks of the existing criminal regime of enforcement for misleading advertising and other deceptive trade marketing practices." 58 As a result, the Act was amended to create a "dual track regime." 59

A representation made, in any form, that is "false or misleading in a material respect" is subject to the Competition Act. ${ }^{60}$ False or misleading advertising is divided into two separate adjudicative regimes under the Competition Act. The criminal regime reviews allegations when there is "clear and compelling evidence that the accused knowingly or recklessly made a false or misleading representation to the public and criminal prosecution is in the public interest." 61 The civil regime, which deals with "reviewable conduct" under Part VII.1 of the Act, titled Deceptive Marketing Practices, includes bait-and-switch selling, misleading ordinary price representations, unauthorized test or testimonial usage, and more. ${ }^{62}$ For the purposes of this article, only the civil regime will be discussed.

Section 74.01(1) of the Act states that a person's actions are reviewable by the tribunal when a person engages in conduct for the purpose of promoting, directly or indirectly, the supply or use of a product or any business interest, by any means whatsoever. This includes making "a representation to the public that is false or misleading in a material respect"; making a representation "to the public in the form of a statement, warranty or guarantee of the performance, efficacy or length of life of a product that is not based on an adequate and proper test thereof, the proof of which lies on the person making the representation"; or making a public representation "in a form that purports to be a warranty or guarantee of a product, or a promise to replace, maintain or repair an article or any part thereof or to repeat or continue a service until it has achieved a specified result, if the form of purported warranty or guarantee or promise is materially misleading or if there is no reasonable prospect that it will be carried out." 63

Section 74.03(4) stipulates that, to qualify as reviewable conduct under section 74.01(1), it is not necessary for the Commissioner to establish that any person was actually misled by the impugned representation, that any of the people allegedly misled by the representation were in Canada, or that the public had access to the place where the representation was made. Remedies and penalties for misleading advertising are found in section 74.1(1). Upon a successful application by the Commissioner of Competition, the tribunal may order that the person(s):

\footnotetext{
${ }^{57}$ Brian R Fraser, "Misleading Advertising and Deceptive Marketing Practices under the Federal Competition Act: A Review of the Last 25 Years and Recent Developments" (2012) 25:2 Can Competition L Rev 485 at 496.

${ }^{58}$ Ibid at 498.

${ }^{59}$ Ibid at 499.

60 "False or Misleading Representations and Deceptive Marketing Practices" (15 November 2015), online: Competition Bureau Canada <www.competitionbureau.gc.ca/eic/site/cb-bc.nsf/eng/03133.html> [Competition Bureau, "Publication"].

${ }^{61}$ Stikeman Elliott, eds, Competition Act and Commentary (Markham, Ont: Butterworths, 2013) at 66.

${ }^{62}$ Competition Bureau, "Publication", supra note 60.

${ }^{63}$ Competition Act, supra note 9, s 74.01(1).
} 
(a) not to engage in the conduct or substantially similar reviewable conduct;

(b) to publish or otherwise disseminate a notice, in such manner and at such times as the court may specify, to bring to the attention of the class of persons likely to have been reached or affected by the conduct, the name under which the person carries on business and the determination made under this section, including

(i) a description of the reviewable conduct,

(ii) the time period and geographical area to which the conduct relates, and

(iii) a description of the manner in which any representation or advertisement was disseminated, including, where applicable, the name of the publication or other medium employed;

(c) to pay an administrative monetary penalty, in any manner that the court specifies, in an amount not exceeding

(i) in the case of an individual, $\$ 750,000$ and, for each subsequent order, $\$ 1,000,000$, or

(ii) in the case of a corporation, $\$ 10,000,000$ and, for each subsequent order, $\$ 15,000,000$; and

(d) in the case of conduct that is reviewable under paragraph 74.01(1)(a), to pay an amount, not exceeding the total of the amounts paid to the person for the products in respect of which the conduct was engaged in, to be distributed among the persons to whom the products were sold-except wholesalers, retailers or other distributors, to the extent that they have resold or distributed the products - in any manner that the court considers appropriate. ${ }^{64}$

Based on these fines, if Live Nation and Ticketmaster are found liable, there could be damaging economic consequences for the companies, not only because of the large number of consumers and honest competitors affected, but also because of the time period over which these allegations extend. Therefore, because of the seriousness of the remedy, an analysis of the case against Live Nation should be explored.

\section{DO LIVE NATION AND TICKETMASTER'S DRIP PRICING PRACTICES BREACH THE COMPETITION ACT?}

In the beginning of 2018, the Bureau proceeded with an application to review the conduct of Live Nation, Ticketmaster, and its subsidiaries under paragraph 74.01(1)(a) and section 74.05 of the Competition Act. ${ }^{65}$ The application alleges that the conduct of these companies constitutes deceptive marketing practices and breaches the Act's misleading advertising provisions.

\footnotetext{
${ }^{64}$ Ibid, s 74.1(1).

${ }^{65}$ CBC, "Competition Bureau Sues Ticketmaster, Live Nation Over Allegations of Inflated Ticket Prices" (25 January 2018), online: $C B C$ News <www.cbc.ca/news/business/competition-bureau-ticketmaster-live-nation-prices$1.4504043>$.
} 
Paragraph 74.01(1)(a) explains that a person who makes a representation to the public that is false or misleading in a material respect or promotes the supply or use of their productdirectly or indirectly - may have their conduct reviewed. ${ }^{66}$ Live Nation and Ticketmaster (and its subsidiaries) made representations to Canadians regarding the online promotion of tickets to sport and entertainment events at a certain price. However, because of additional mandatory fees, the promoted prices were not actually attainable. As the Competition Bureau's application explains, the websites Ticketmaster.ca, ticketweb.ca, and ticketsnow.com present initial tickets for purchase with one price listed under a "Buy on Map" tab. ${ }^{67}$ After customers navigate through the purchasing process, mandatory fees are added to the true cost of the tickets. These fees allegedly increase ticket costs by 20 to 65 percent. ${ }^{68}$ A countdown clock is also present at times to pressure consumers, through fear of loss, into purchasing tickets. ${ }^{69}$ The Competition Bureau noted that on August 21, 2017, the price of a single ticket to a OneRepublic concert increased by $\$ 45.80$ because of fees. $^{70}$

At other times, the websites will have the words "+ Fees" next to the ticket prices. ${ }^{71}$ However, as the Competition Bureau points out, the true costs of the fees are still unknown to the consumer, despite being allegedly known by the company in advance. ${ }^{72}$ This begs the question as to whether or not the companies sporadically and unpredictably change their fees. Therefore, the uncertainty with which these fees are calculated constitutes a misleading representation under s 74.01(a).

An example of this occurred in Vancouver in 2017, as the cost for concert tickets for the band Nickelback was outlined as "\$50 + fees" on Ticketmaster's websites for both "Standard Tickets" and "Verified Resale Tickets. ${ }^{73}$ However, upon completion of the steps on the website, the price of a pair of standard tickets amounted to $\$ 140.60$, while the final cost for the resold tickets was merely $\$ 117.00$. The decision by Ticketmaster to add an increased 40 percent in fees to the standard tickets, but only a 17 percent increase in fees to resale tickets, appears to mislead the customer. ${ }^{74}$ These drip pricing tactics appear to be contrary to the Competition Act policies of fair and transparent business practices. ${ }^{75}$

\footnotetext{
${ }^{66}$ Competition Act, supra note 9, s 74.01(1)(a).

${ }^{67}$ Competition Tribunal, “Application", supra note 40 at para 43.

${ }^{68} \mathrm{Ibid}$ at para 5.

${ }^{69}$ Ibid at para 26.

${ }^{70}$ Ibid at para 37.

${ }^{71}$ Ibid at para 44.

${ }^{72}$ Ibid.

${ }^{73}$ Ibid at para 47. See Figure 3. Verified Resale Tickets are Secondary Market tickets resold on their own website.

${ }^{74}$ Ibid at para 49. See Figure 4.

75 "Competition and Compliance Framework," (10 November 2015), online: Competition Bureau Canada <www.competitionbureau.gc.ca/eic/site/cb-bc.nsf/eng/03982.html>.
} 

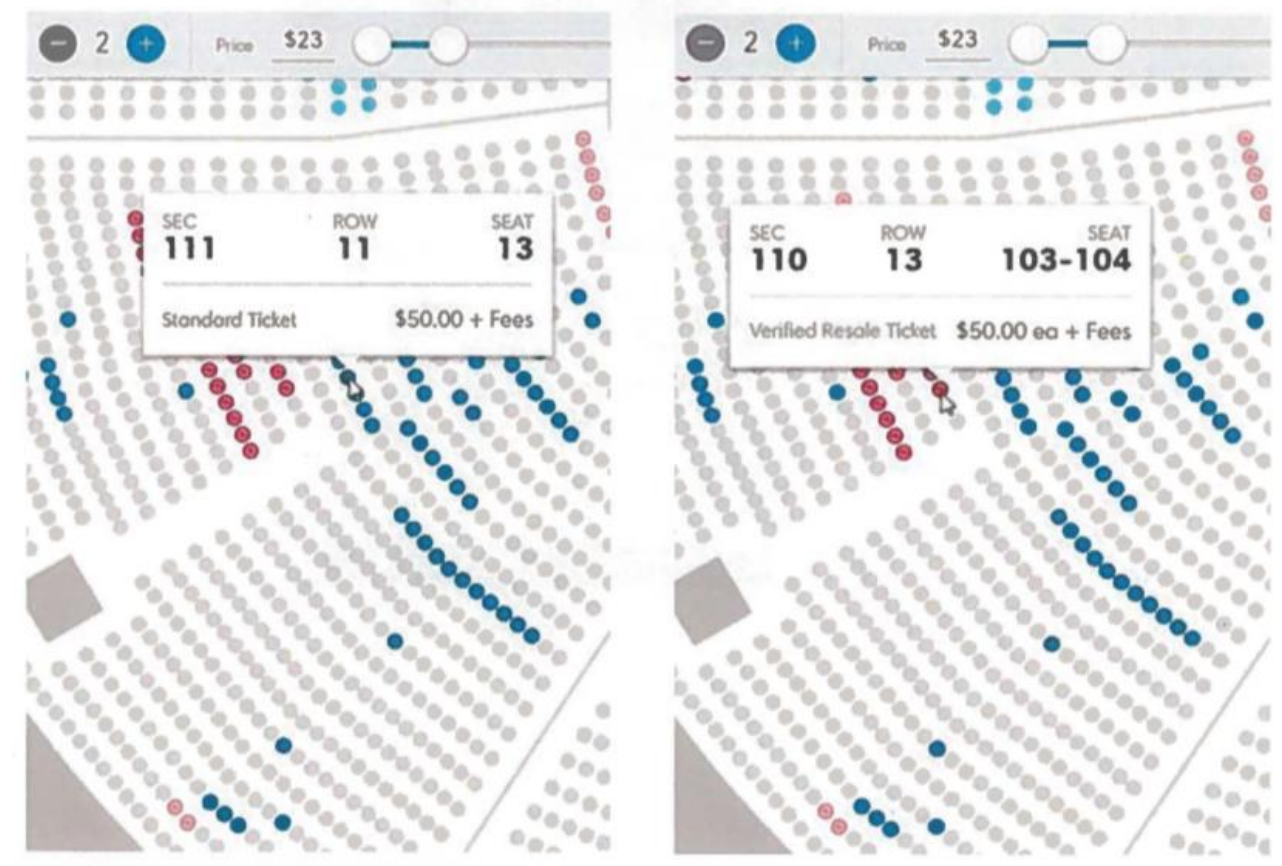

Figure 3: Standard Ticket and Verified Resale Ticket Prices ${ }^{76}$
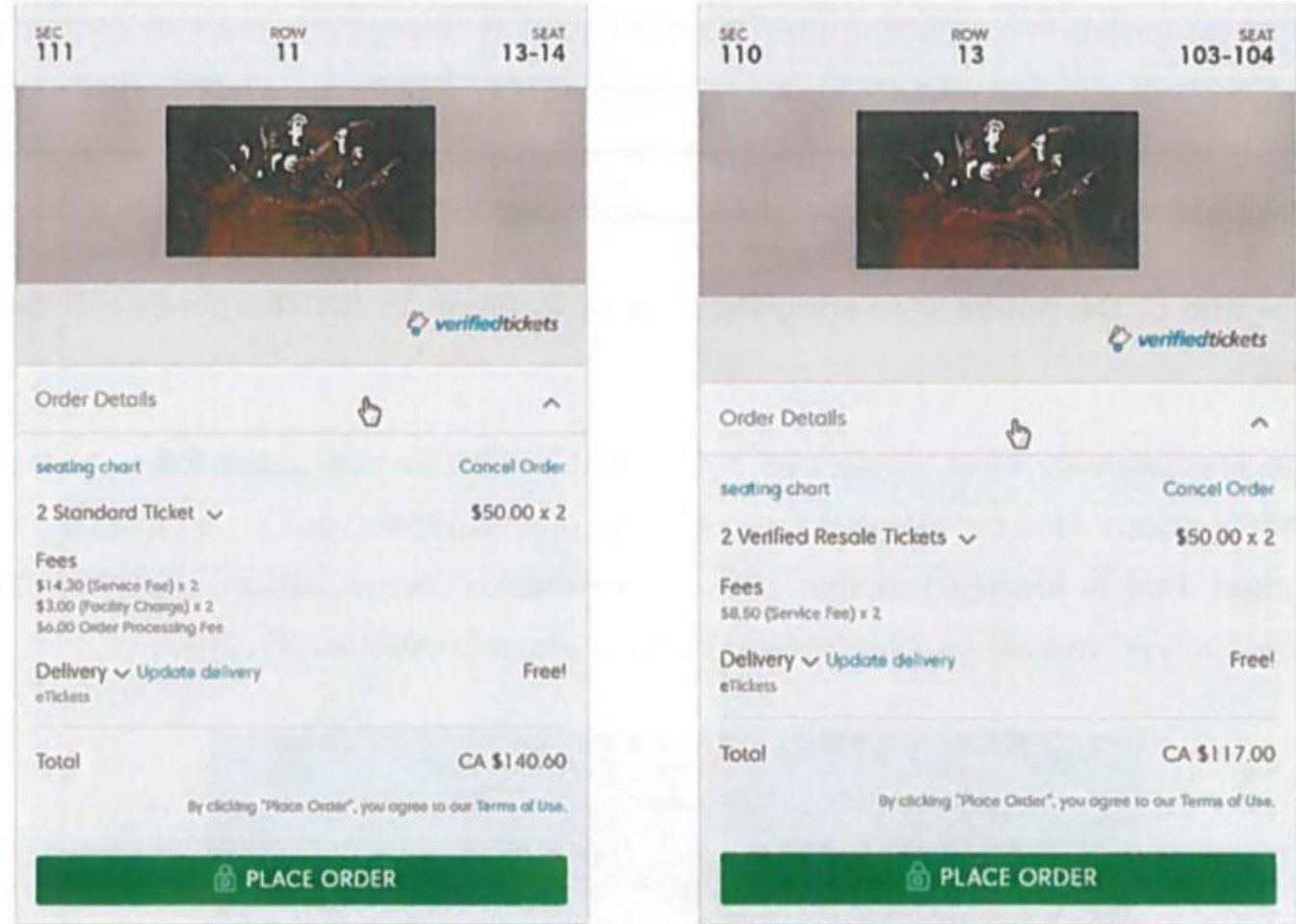

Figure 4: Difference in fees between standard ticket and verified resale ticket prices ${ }^{77}$

${ }^{76}$ Competition Tribunal, “Application”, supra note 40 at para 47. Photos retrieved from Application.

${ }^{77}$ Ibid at para 48. 
Because ticket price is a major deciding factor for consumers, price can be interpreted as a material fact for the purposes of section 74.01(1)(a). In addition, failing to disclose hidden fees or the way fees are calculated could constitute misleading or false representations. Therefore, there is a strong argument that these companies have engaged in reviewable conduct under section 74.01(1)(a).

Section 74.05 explains that a person who advertises a product "for sale or rent in a market and, during the period and in the market to which the advertisement relates, supplies the product at a price that is higher than the price advertised,"78 will be subject to review. This section effectively prevents people from selling their products at prices higher than initially advertised unless one of the four exceptions outlined in the Act are met. ${ }^{79}$ As Ticketmaster initially advertised the tickets at a lower price than the final price to be paid once fees were added, this may be classified as reviewable conduct.

\section{LIVE NATION AND TICKETMASTER'S RESPONSE}

In response to these allegations, Live Nation and Ticketmaster argue that their practices are "transparent, pro-consumer and proper." 80 Their argument centres on the idea that they eventually disclose the fees to the consumer, often through "obvious fee signals," and that, since consumers are aware that the fees will be included later, the representations are not misleading. ${ }^{81}$ Furthermore, the companies argue that nothing in the Competition Act explicitly mentions drip pricing and that the Competition Bureau is trying to "apply general provisions of the Act to conduct that they were not intended to cover." 82

With respect to ticket pricing, Ticketmaster explains that their clients set the face value of a ticket; therefore, Ticketmaster retains none of that revenue. ${ }^{83}$ Ticketmaster then adds its fees after negotiations with its clients. ${ }^{84}$ Some of these fees are retained as revenue by Ticketmaster, but the company explains that other fees are entirely retained by their clients. ${ }^{85}$ The purpose of these fees varies. According to Ticketmaster, some fees, such as their "service fees," are charged so that customers can "avoid the need to go in person to a venue box office or retail outlet" and are shared between the clients and company. ${ }^{86}$ The amount of fees charged depends on certain factors, such as the client's identity, the venue, the event's jurisdiction, the unit price, and the number of tickets available. ${ }^{87}$

\footnotetext{
${ }^{78}$ Competition Act, supra note 9, s 74.05(1).

${ }^{79} \mathrm{Ibid}$, s 74.05(2).

${ }^{80}$ Competition Tribunal, "Response", supra note 41 at para 1.

${ }^{81}$ Ibid at paras 2-3.

${ }^{82} \mathrm{Ibid}$ at para 4.

${ }^{83} \mathrm{Ibid}$ at para 20.

${ }^{84} \mathrm{Ibid}$ at para 21.

${ }^{85} \mathrm{Ibid}$ at para 22.

${ }^{86} \mathrm{Ibid}$ at paras 26-27.

${ }^{87} \mathrm{Ibid}$ at para 23.
} 
In addressing the sequence by which the fees get added to the total cost, Ticketmaster explains that the Competition Bureau has mischaracterized their process. ${ }^{88}$ The company uses the term "buy flow" with regard to the "screen-by-screen and button-by-button process used by customers to purchase products." The buy-flow process, Ticketmaster explains, "transparently guides consumers through each element" so that consumers become aware of the price as they reach the final screen. ${ }^{89}$ Ticketmaster's position is that the initial price should not be treated as a representation of the final cost, and consumers should not expect it to be so. ${ }^{90}$ Buttons like "Buy Tickets," Ticketmaster argues, are traditional e-commerce jargon that do not express a final price. ${ }^{91}$ Ticketmaster supports this argument by explaining that the fees added are similar to other online retailers who add shipping costs at the end of a transaction, ${ }^{92}$ and, thus, the addition of fees is consistent with e-commerce practices.

Furthermore, Ticketmaster alleges that they remind customers that the initial ticket price will not be the final price during this buy-flow method by using "obvious fee signals." 93

These "obvious fee signals" include statements explaining that "fees apply to the face value of a ticket and/or that additional fees will be applied at checkout," as well as the description of the ticket's face value as a "subtotal." Ticketmaster also provides customers with links to answer questions about the fees at checkout, appropriately titled "We know no one's a fan of fees/ Learn why they're here." "94 In addition, Ticketmaster states that they have "pop-up" or "shadow boxes" that appear over certain information during this process. ${ }^{95}$

Ticketmaster provides an example of these "obvious fee signals" for a Toronto Raptors game (see Figure 5). A list of available tickets is provided. Upon selecting the tickets, customers are advised next to the cost of the ticket that fees are applicable, ${ }^{96}$ then a customer clicks on "GET TICKETS" to obtain the final price (see Figure 5). ${ }^{97}$

In response to the Commissioner's claim that the time limit constraints - emphasized by a clock-force consumers to make expedient decisions, Ticketmaster explains that the clocks are actually pro-consumer tools that "ensure the fair and equitable distribution of tickets to popular events." ${ }^{98}$ Since the ticketing industry provides limited product to an endless number of

\footnotetext{
${ }^{88} \mathrm{Ibid}$ at para 39.

${ }^{89}$ Ibid.

${ }^{90}$ Ibid at para 40.

${ }^{91}$ Ibid at para 47.

92 Ibid at para 44.

${ }^{93} \mathrm{Ibid}$ at paras 2-3.

${ }^{94} \mathrm{Ibid}$ at para 53.

${ }^{95}$ Ibid.

${ }^{96} \mathrm{Ibid}$ at para 58.

${ }^{97}$ Ibid.

${ }^{98} \mathrm{Ibid}$ at para 60.
} 
consumers, an "equitable distribution of tickets" must be ensured. ${ }^{99}$ Therefore, Ticketmaster's position is that these buy-flow clocks ensure that customers can access available tickets. ${ }^{100}$

\begin{tabular}{|c|c|}
\hline Lowest Price & Best Seats \\
\hline $\begin{array}{l}\text { Sec 11, Row H } \\
\text { Standard Ticket }\end{array}$ & CA $\$ 9.05$ \\
\hline $\begin{array}{l}\text { Sec 11, Row J } \\
\text { Standard Ticket }\end{array}$ & CA $\$ 9.05 \mathrm{eo}$ \\
\hline $\begin{array}{l}\text { Sec 24, Row H } \\
\text { Standard Ticket }\end{array}$ & CA $\$ 9.05$. o \\
\hline $\begin{array}{l}\text { Sec 24, Row J } \\
\text { Standard Ticket }\end{array}$ & CA $\$ 9.05$ \\
\hline $\begin{array}{l}\operatorname{Sec} 26 \text {, Row J } \\
\text { Standard Ticket }\end{array}$ & CA $\$ 9.05$ ea \\
\hline $\begin{array}{l}\operatorname{Sec} 26 \text {, Row F } \\
\text { Standard Ticket }\end{array}$ & CA $\$ 9.05$ \\
\hline $\begin{array}{l}\operatorname{Sec} 26 \text {, Row G } \\
\text { Standard Ticket }\end{array}$ & CA $\$ 9.05$ ea \\
\hline $\begin{array}{l}\text { Sec } 26 \text {, Row H } \\
\text { Standard Ticket }\end{array}$ & CA $\$ 9.05$ ea \\
\hline $\begin{array}{l}\text { Sec 11, Row P } \\
\text { Standard Ticket }\end{array}$ & CA $\$ 9.05 .0$ \\
\hline $\begin{array}{l}\text { Sec 11, Row Q } \\
\text { Standard Ticket }\end{array}$ & CA $\$ 9.05$ ec \\
\hline $\begin{array}{l}\text { Sec 11, Row R } \\
\text { Standard Ticket }\end{array}$ & CA $\$ 9.05$ \\
\hline
\end{tabular}

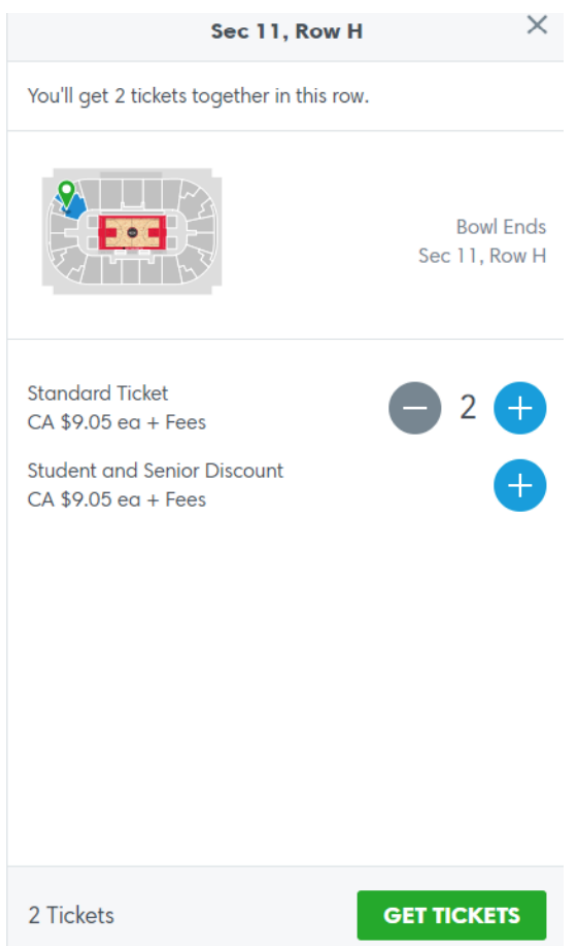

Figure 5: Buy-flow system argued by Live Nation and Ticketmaster ${ }^{101}$

With regard to the allegation under section 74.05, the respondents argue that the section only applies to advertisements. ${ }^{102}$ The companies explain that their initial listed prices are not advertisements but simply displays of prices. ${ }^{103}$ In the alternative, Ticketmaster argues that their advertisement is followed by an advertisement correcting the price, an exception under section 74.05(2). In all, Ticketmaster and Live Nation deny that their buy-flow method contravenes the Competition Act.

\section{REBUTTAL AGAINST LIVE NATION AND TICKETMASTER}

Live Nation and Ticketmaster's arguments rely on the premise that consumers are not misled by the buy-flow screens because they are constantly reminded of the fees throughout the

\footnotetext{
${ }^{99}$ Ibid at para 62.

${ }^{100}$ Ibid.

${ }^{101}$ Ibid at paras 57-58. Photos retrieved from Response.

102 Ibid at para 76.

${ }^{103}$ Ibid at para 77.
} 
buy-flow process by "obvious fee signals." 104 Notably, it is not necessary under the Competition Act to prove that any consumer is actually misled, but rather that the representations per se are misleading. ${ }^{105}$ The added fees can therefore still be misleading as they are subject to change and are calculated based on a variety of factors. Unlike shipping costs, which are disclosed with the calculated price and are not subject to change, or taxes, which have a fixed, calculable rate, the fees these companies charge are arbitrary and can result in substantially higher prices than anticipated. For these reasons, the representations are misleading despite the buy-flow method.

The arguments of Live Nation and Ticketmaster are construed in a way to show that consumers are not in a rush to purchase tickets. This fails to consider the realities of ticket purchasing. Depending on the popularity of the performer, many concerts will either sell out in seconds, while some may be unlikely to be available again, such as the Tragically Hip's final tour. Ticketmaster's consumers are extraordinarily motivated to obtain tickets to these events. When a consumer goes online, the clock begins to count down and the consumer must act fast to obtain a ticket. The initial price displayed is a significant deciding factor underlying the consumer's choice of ticket. However, once the final cost is displayed, the customer has little choice and no room to negotiate the fees. Restarting the process to find a cheaper ticket poses the risk of finding the concert sold out. Furthermore, consumers do not have time to read Ticketmaster's links, which provide ambiguous explanations of why the fees are present. This reality undermines the argument of transparency with regard to fee practices. If Ticketmaster truly wanted to be transparent, the full ticket price would appear on the first screen. The "obvious fee signals" merely obfuscate the process, which results in fans being surprised later, with little recourse.

The buy-flow system intimidates consumers and either fails to recognize or purposely ignores the commercial realities faced by fans. Buttons like "GET TICKETS" create the "unambiguous general impression for consumers that the [prices] represent the price for tickets" and not merely the initial tickets themselves. ${ }^{106} \mathrm{~A}$ consumer could hypothetically move through the website unaware of the cost of these fees. Therefore, the buy-flow method is a misleading structure that presents an initial enticing price and subsequently forces consumers to make a quick decision about their tickets once the non-optional fees are included. Therefore, the representations may still constitute reviewable conduct under section 74.01(1)(a). In any event, Ticketmaster's conduct is certainly not pro-consumer, especially given their acknowledgment that "no one's a fan of fees." 107

While the companies may argue that their disclosure of "+ Fees" on the website exempts them from their obligation to comply with section 74.05 since it could constitute a second advertisement under section 74.05(2)(b), this argument falls short upon further scrutiny. In particular, the distinction made by Live Nation and Ticketmaster hinges on the argument that their price listings do not constitute an advertisement. The distinction that a ticket price posting is not

\footnotetext{
${ }^{104}$ Ibid at paras 2-3.

105 Competition Act, supra note 9, s 74.03(4).

${ }^{106}$ Competition Tribunal, "Reply", supra note 51 at para 11.

${ }^{107}$ Competition Tribunal, "Response", supra note 41 at para 53(d).
} 
an advertisement demands a very literal understanding of what constitutes an advertisement. With no definition of what an advertisement is under the Act, however, this could be a contested issue.

How these problems will play out is uncertain. Little prior case law has dealt with these buy-flow structures. However, parallels can be drawn between this case and allegations against car rental companies over the last few years. In 2015, the Competition Bureau filed an application against Avis and Budget, arguing that certain non-optional fees, such as the "tire management fee," "energy recovery fee," and "Ont. environ fee" were added to the total cost of car rentals. 108 The hidden fees typically increased the true cost by approximately 35 percent. ${ }^{109}$ The Bureau alleged that this conduct was reviewable under sections 74.01(1)(a) and 74.05, explaining that the inclusion of fees constituted reviewable conduct. ${ }^{110}$ The issue was settled in 2016. As part of their settlement, Avis and Budget agreed to a \$3 million penalty, $\$ 250,000$ toward the Bureau's costs, and the implementation of a corporate compliance program to promote compliance with the Competition Act. ${ }^{111}$ This case shows that the arguments against Ticketmaster and Live Nation may hold. However, as the Avis issue resulted in a settlement, it is difficult to conclude the likelihood of the Competition Bureau's success against Ticketmaster at the tribunal.

Even if Ticketmaster's conduct is determined to be punishable, consideration must be given to the remedy. In 2003, two Americans filed a class-action lawsuit against Ticketmaster under California's Unfair Competition Law. ${ }^{112}$ Their claim alleged that Ticketmaster's "description of its fees on its Website ... is deceptive and suggested that Ticketmaster's expedited delivery fee ("Delivery Price") and order processing fee (“OPF"), read in the context of the description of other Ticketmaster fees that allegedly were deceptively described too, were the same as or based on expedited delivery and order processing costs."113 Ten years later, a settlement was reached. The settlement entitled any consumer who purchased tickets between October 1999 and February 2013 from Ticketmaster to between one and seventeen "discount codes worth a $\$ 2.25$ credit each when applied toward subsequent purchases of primary tickets on the Website for events in the United States." ${ }^{114}$ In addition, class members received codes that could be redeemed for two general admission concert tickets at Ticketmaster. However, while

\footnotetext{
${ }^{108}$ The Commissioner of Competition vs Aviscar Inc, Budgetcar Inc/Budgetauto Inc, Avis Budget Group, Inc and Avis Budget Car Rental, LLC, "Notice of Application" (11 March 2015) at para 16, online: Competition Tribunal <www.ct-tc.gc.ca/CasesAffaires/CasesDetails-eng.asp?CaseID=375>.

${ }^{109}$ Ibid at para 19.

${ }^{110}$ Ibid at para 1(a).

111 The Commissioner of Competition vs Aviscar Inc, Budgetcar Inc/Budgetauto Inc, Avis Budget Group, Inc and Avis Budget Car Rental, LLC, "Registered Consent Agreement" (2 June 2016) at paras 5-6, 8, online: Competition Tribunal <www.ct-tc.gc.ca/CMFiles/CT-2015-001_Registered\%20Consent\%20Agreement_82_66_6-2-

2016_6072.pdf>.

112 Curt Schlesinger and Peter Lo Re v Ticketmaster, Los Angeles Superior Court Case No. BC 304565; online: Ticket Fee Litigation <www.ticketfeelitigation.com/court>.

${ }^{113}$ Curt Schlesinger and Peter Lo Re v Ticketmaster, Los Angeles Superior Court Case No. BC 304565, “Settlement Agreement and Release" (7 June 2013) at para I.B., online: Ticket Fee Litigation <www.ticketfeelitigation.com/ docs/sa.pdf $>$.

${ }^{114}$ Ibid, s 2.1.
} 
Ticketmaster may have lost US\$39.6 million from the ticket vouchers, the company was allowed to choose which events and venues were subject to these vouchers, meaning many consumers were unable to redeem their vouchers. ${ }^{115}$ If the tribunal implemented a remedy like this, it would be wholly inadequate to fix the current situation. Therefore, notwithstanding the outcome of the Competition Bureau's application, other possible solutions to this problem should be considered.

\section{WHAT NEEDS TO CHANGE?}

As of December 2018, Ticketmaster has begun to change their ticket advertisements by posting the final ticket price at the beginning of the transaction. As illustrated in Figure 6, tickets to Ariana Grande's "Sweetener" tour, one of the more popular events in $2019,{ }^{116}$ now show a final price listed, followed by a breakdown of fees in brackets.
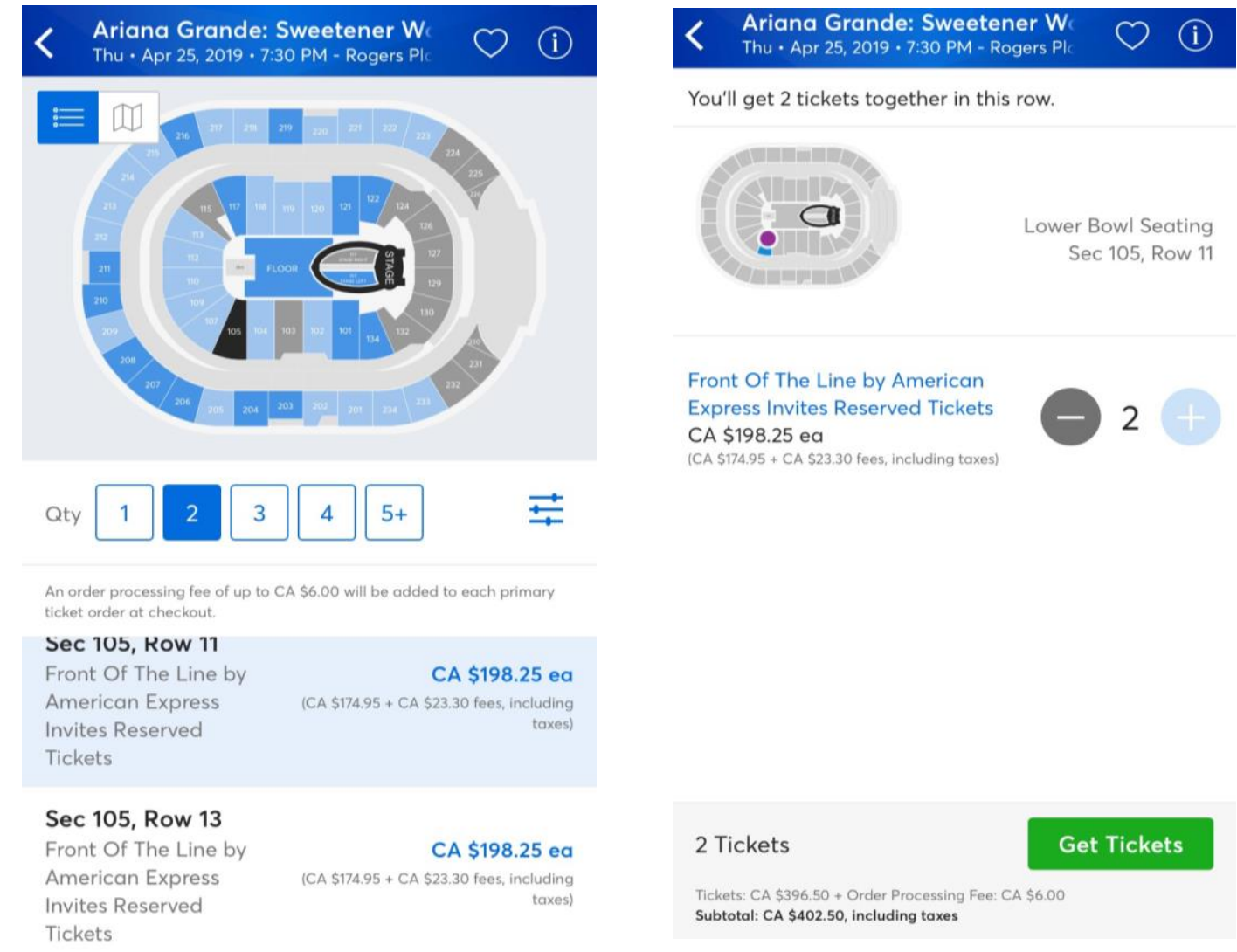
Front Of The Line by American Express Invites Reserved Tickets CA $\$ 198.25$ ea (CA $\$ 174.95+$ CA $\$ 23.30$ fees, including taxes)

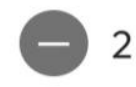

2

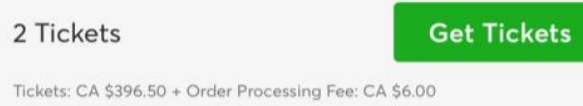

Tickets: CA $\$ 396.50+$ Order Processing Fee: CA $\$ 6.00$ Subtotal: CA $\$ 402.50$, including taxes

Figure 6: Tickets to Ariana Grande's "Sweetener" Tour, showing the final price from the start ${ }^{117}$

\footnotetext{
${ }^{115}$ Daniel Victor, "Why You Probably Won't Get to Use Your Ticketmaster Vouchers" (June 21, 2016), online: The New York Times <www.nytimes.com/2016/06/22/business/media/ticketmaster-lawsuit-vouchers.html>. ${ }^{116}$ Bre Williams, “Ariana Grande's 'Sweetener' World Tour Is So Popular, She's Already Adding Extra Concert Dates in 2019" (12 December 2018), online: The Cheat Sheet <www.cheatsheet.com/entertainment/ariana-grandessweetener-world-tour-is-so-popular-shes-already-adding-extra-concert-dates-in-2019.html/> .

117 These ticket prices were screen-captured from Ticketmaster's mobile website for the Edmonton, Alberta show, set for April 25, 2019.
} 
Whether Ticketmaster has decided to make these changes to avoid a larger monetary penalty pending an unfavourable judgment by the Competition Tribunal is uncertain. However, the change, made barely a year after the Competition Bureau's application, certainly raises questions. Despite these recent changes, Live Nation and Ticketmaster still control an overwhelming portion of the live entertainment industry. Current antitrust and competition laws in both the United States and Canada do not appear to be adequate to curb these practices, and such failures have "hindered competition." "118 Without provincial or federal changes to curb their monopoly, "Ticketmaster has no incentive to lower prices," and consumers will be hindered from making "a meaningful choice in deciding which live event to attend." 119 Therefore, longterm solutions to this issue must be examined.

The lack of regulation in this area has enabled Ticketmaster to not only charge exorbitant service fees, but also to reap benefits in the secondary industry. In the United States, the federal government has attempted to curb these practices in both markets. In 2009, the Better Oversight of Secondary Sales and Accountability in Concert Ticketing Act of 2009 was introduced, and was aimed at protecting consumers "from unfair and deceptive acts and practices in connection with primary and secondary ticket sales." ${ }^{120}$ However, the bill was stalled after being referred to the House Committee on Energy and Commerce. ${ }^{121}$ The bill was then reintroduced in 2016, with a goal of forcing primary ticket sellers to disclose the total number of tickets offered, the "distribution method of tickets not available to the general public," the disclosure of all fees, and more. ${ }^{122}$ However, the bill once again stalled after being referred to the Subcommittee on Commerce, Manufacturing and Trade. ${ }^{123}$

In Canada, Quebec is currently the only province with legislation in place to tackle drip pricing through all-inclusive pricing laws. Section 224 of Quebec's Consumer Protection Act states that the "total amount the consumer must pay for the goods and services" must be included in the amount advertised. ${ }^{124}$ Ontario is now attempting to follow suit with Bill 190, the quite literally titled What You See is What You Pay Act (Consumer Protection Amendment), 2017. ${ }^{125}$ The amendment aims at requiring suppliers to "ensure that any information provided to a

\footnotetext{
${ }^{118}$ Grzegorek, supra note 45 at 281.

${ }^{119}$ Ibid at 282.

${ }^{120}$ Better Oversight of Secondary Sales and Accountability in Concert Ticketing Act of 2009, HR 2669, 111th Congress, 2009, online: <www.congress.gov/111/bills/hr2669/BILLS-111hr2669ih.pdf>.

${ }^{121}$ Klein, supra note 4 at 203.

${ }^{122}$ Better Oversight of Secondary Sales and Accountability in Concert Ticketing Act of 2016, HR 5245, 114th Congress, 2016, online: <www.congress.gov/114/bills/hr5245/BILLS-114hr5245ih.pdf>.

123 “All Actions HR 5245-114th Congress (2015-2016)" (20 May 2016), online: Congress.gov

<www.congress.gov/bill/114th-congress/house-bill/5245/all-actions>.

${ }^{124}$ Consumer Protection Act, CQLR c P-40.1, s 224(c).

${ }^{125}$ Bill 190, An Act to amend the Consumer Protection Act, 2002 to require suppliers to disclose an all-inclusive cost, 2nd Sess, 41st Leg, Ontario, 2017, online: <www.ola.org/sites/default/files/node-files/bill/document/ pdf/2017/2017-12/bill---text-41-2-en-b190_e.pdf>.
} 
consumer regarding the cost of a good or service includes an all-inclusive cost." 126 After the bill's first reading in late 2017 , however, no further action has been taken. ${ }^{127}$

\section{FEDERAL LAWS SHOULD BE IMPLEMENTED}

The discrepancies in pricing laws across different Canadian provinces present problems not only for consumers, but also for companies such as Ticketmaster. A single tour may require Ticketmaster to adhere to different provincial laws, depending on where the concerts are held. While Ticketmaster has acknowledged its adherence to Quebec's inclusive pricing laws, ${ }^{128}$ such provincial laws made sense when people purchased their tickets at box offices. Technology and globalization have made the variations between provinces a cumbersome burden. What may be required, instead, is action by the federal government to implement or amend current laws regarding both secondary and primary market practices to provide greater certainty to consumers and to reflect technological advances in today's market.

The concepts of deceptive marketing and pricing regulation are concepts of mixed jurisdiction. The Supreme Court of Canada has explained the relationship between the federal Competition Act and provincial consumer protection legislation, first in General Motors of Canada Ltd $v$ City National Leasing ${ }^{129}$ and more recently in Reference re Pan-Canadian Securities Regulation, ${ }^{130}$ as follows:

In General Motors, affirmative answers with respect to these indicia supported the validity of a federal statute that regulated anti-competitive behaviour. Dickson C.J., writing for the Court, described the impugned Combines Investigation Act, R.S.C. 1970, c. C-23 (now the Competition Act, R.S.C. 1985, c. C-34) as "a complex scheme of competition regulation aimed at improving the economic welfare of the nation as a whole" which was "designed to control an aspect of the economy that must be regulated nationally if it is to be successfully regulated at all" (p. 682). The subject matter of the legislation therefore fell within Parliament's power over trade and commerce even though the provinces are also competent to "deal with competition in the exercise of their legislative powers in such fields as consumer protection, labour relations, marketing and the like" (p. 682). ${ }^{131}$

\footnotetext{
${ }^{126}$ Ibid (see Explanatory Note).

127 Yvan Baker, "Status: Bill 190, What You See is What You Pay Act (Consumer Protection Amendment), 2017" (2017), online: Legislative Assembly of Ontario <www.ola.org/en/legislative-business/bills/parliament-41/session2/bill-190/status>.

${ }^{128}$ Competition Tribunal, "Response", supra note 41 at para 87.

${ }^{129}$ General Motors of Canada Ltd v City National Leasing, [1989] 1 SCR 641.

${ }^{130}$ Reference re Pan-Canadian Securities Regulation, 2018 SCC 48.

${ }^{131}$ Ibid at para 104.
} 
While the constitutionality of creating federal laws regarding all-inclusive pricing, drip pricing, and the legality of ticket bots would be the subject of another paper entirely, federal implementation of such laws would be a fairer and more efficient approach. While Ticketmaster argues that its "obvious fee signals" attempt to inform consumers that fees will be included later in their purchase, the total cost of the ticket still does not appear until the final purchasing step. However, once consumers reach the end of their purchasing process, the ticket price may not accurately reflect the initially enticing price. If such tickets were for a popular event, customers would be forced to choose between not going to the event or paying a higher price-leading to an unfair result. Laws enforcing all-inclusive pricing would avoid such a result by allowing consumers to understand the true cost of their tickets, and would allow "secondary purchasers to understand the true cost of the ticket and to accurately compare the prices offered between the primary and secondary sellers." ${ }^{132}$ Federal laws would also be a more efficient solution since they would provide greater certainty for ticketing agencies. Companies' websites would only need to follow one set of pricing rules, as opposed to being forced to change their websites for different provinces and territories.

Arguments have also been put forward that the secondary market and ticket scalping are beneficial for the economy since they stimulate competition and make it "easier for consumers to buy tickets to an event in the resale market, as long as they are willing to pay market-driven prices." ${ }^{133}$ However, such arguments are unconvincing. Ticket bots are able to acquire enormous amounts of tickets at one time. ${ }^{134}$ These bots skew the market as they can "purchase more tickets than a consumer not using the software would be able to purchase," leaving regular fans to purchase tickets at prices far higher than on the primary market. ${ }^{135}$ Such a technology does not promote a free market, but uses a technology inaccessible to others to gain an unfair advantage. Therefore, federal legislation banning ticket bots promotes more equal access in the market.

If such laws cannot be implemented, it may be incumbent on the Competition Bureau and the federal government to determine a way to make such problems more prosecutable, either through regulations or tribunal procedure. The implementation of blockchain technology into ticket distribution may also be an option to curb the prevalence of ticket bots. Blockchain is an online distribution ledger that "reconfigures the electronic infrastructure by which tickets are distributed and ticketing transactions are recorded." 136 This technology could then "limit the number of tickets any one consumer may purchase" or stop tickets from being resold after a certain period of time. ${ }^{137}$ BitTicket, a current contender in this area, uses blockchain to prevent

\footnotetext{
${ }^{132}$ Klein, supra note 4 at 205.

${ }^{133}$ Phillip Leslie \& Alan Sorensen, "Resale and Rent-Seeking: An Application to Ticket Markets" (2014) 81:1 Rev Economic Stud 81:1 266 at 298, DOI: <10.1093/restud/rdt033>.

${ }^{134}$ Sisario, supra note 27.

${ }^{135}$ Dylan C Porcello, "A Fixed Game: The Frustrations of Ticket Scalping and the Realities of Its Solutions" (2018) 84:1 Brook L Rev 259 at 267.

${ }^{136}$ Sammi Elefant, "Beyond the Bots: Ticked-Off Over Ticket Prices or The Eternal Scamnation (2018) 25:1 UCLA Ent L Rev 1 at 37, permalink: <escholarship.org/uc/item/056242s2>.

${ }^{137}$ Ibid.
} 
sales on the secondary market through "anti-fraud sales rules to ensure that no secondary ticket website can hoard tickets" and increase ticket prices. ${ }^{138}$ Any attempt to resell the ticket on a secondary website would freeze the seller's BitTicket account, and the purchased tickets would be cancelled. ${ }^{139}$ Whether this technology, if widely adopted, would effectively remove the need for the secondary market remains to be seen; however, it would certainly assist in removing the possibility of ticket bots.

Finally, another potential avenue for change is for Parliament to impose disclosure obligations on companies that implement fees. Such disclosure obligations would require information about how the fees are calculated, whether or not they are subject to increase, and the programs used to calculate them. Conversely, disclosure requirements for fees and their calculation processes may result in additional compliance costs for ticket distribution companies. Such costs may then be passed on to consumers, resulting in dissatisfied customers and consequences for smaller businesses attempting to enter the ticketing market, or in other areas where hidden fees provide income. However, what these requirements attempt to promote is consumer protection, which, at the end of the day, may cost money. Therefore, such requirements would come down to conducting a cost-benefit analysis and deciding whether the benefit to the consumer would exceed the cost of small businesses complying. Furthermore, another result might be that the costs of complying with these disclosure obligations would be less than the current costs imposed in an unregulated market. While these strategies may not relieve Live Nation and Ticketmaster of their behemoth status in the entertainment industry, they will certainly enable consumers to make prudent and fair decisions when purchasing tickets.

\section{CONCLUSION}

Currently, Ticketmaster and Live Nation are engaging in deceptive marketing practices, and the Competition Bureau's recent application to stop these practices is a step in the right direction. In addition, Live Nation and Ticketmaster's arguments regarding these practices are unconvincing and, ideally, any penalties given by the tribunal will prevent these activities from recurring. If, however, the results of the application prove unfavourable to the Competition Bureau, federal legislation should be implemented to stop these practices in order to allow consumers to make prudent and informed decisions when purchasing tickets.

\footnotetext{
${ }^{138}$ Rebecca Campbell, "Using Blockchain Tech to Keep Concert Tickets Honest” (24 May 2017), online: Bitcoin Magazine <bitcoinmagazine.com/articles/using-blockchain-tech-keep-concert-ticket-prices-honest>.

${ }^{139}$ Ibid.
} 